\title{
The influence of brand clothing display design of apparel sales
}

\author{
Xiaoming $\mathrm{Tu}^{1, \mathrm{a}}$ \\ ${ }^{1}$ Jiangxi Institute of Fashion Technology, Jiangxi, Nanchang, 330201 \\ a178520969@qq.com
}

Keywords: Brand; Display design; Clothing sales; Brand culture

\begin{abstract}
For now the brand clothing shop, store design quality directly affects the brand image, the merchandising stores, a direct impact on consumers for goods, also affects the store sales performance. So the design of the store and display design be reckoned, now more and more brand clothing to store design and display design, they will pass the audience for the brand, the consumer psychology, so as to promote commodity aesthetic feeling on the vision, at the same time show the commodity culture, stimulate consumer purchasing desire, thus increasing sales profit. In this article, through actual investigation and study clothing brand "pure" to reflect this argument, from the consumer's psychology, store sales performance analysis, and show clothing store design and display design of apparel sales.
\end{abstract}

\section{Introduction}

Clothing store is now main clothing sales terminals, the design of the stores of the subjective influence the commodity sales profits, brand clothing mainly through the design of goods in store and display design to reflect the brand culture, thus through the power of the brand clothing enterprises occupy a certain position in the garment industry. Display design through visual aesthetic, let consumer can subjective understanding of the brand culture, and to the brand positioning, have certain consumer groups. Today's fashion brand more and more attention by store design and display design to increase corporate profits.

More and more individual business households, let more clothing brands to display design and shop design pay more attention to, regardless of the size of the brand now has a professional design team to study the commodity exhibition, through a unique pattern to highlight the difference between the brand and other brands, with the influence on consumers to enhance the brand status. So the store design and display design is the key to the commodity marketing, only seize the consumer's "eyes", to better sales.

Visual art is not just a behavior art, as a kind of visual aesthetic art, the audience more and more high to the requirement of visual art, taste is more and more unique. And the visual arts in the apparel industry through the use of colour, modelling, collocation, shape, light and shade, props to express goods, at the same time show the brand culture. If consumers attracted to distinctive products, at the same time there is demand of choose and buy, then this kind of visual art marketing is successful. So now the clothing store visual merchandising was the key to influence the sales profit. In the clothing industry increasingly competitive today, how to seize the consumer's psychology, how to highlight the brand culture and how to get the terminal retail do benefit maximization, all be carefully research topic. In this paper, the clothing store design and display effect on clothing sales, with the help of a clothing brand pure to analyze this topic, and objective conclusions.

\section{Clothing store design and display design}

The development of the store design and display design. "Monopoly" itself means most exclusive sales, only a particular individual has the right of selling a product, the product operating profit, and only he could have all sorts of information of the product. Mainly refers to the brand clothing in the clothing industry by a certain form, have the right to the brand clothing research and development by the sale of goods. Today, clothing stores more to brand stores this brand specializes in marketing. Therefore, clothing store is one of the main consumers purchase channels, through the 
store design and display design to embody clothing brand image, so that consumers understand the brand culture, let the brand value, further enhance brand awareness, to maximize the brand value.

The word "display design" originating in Europe, in some European countries artists put goods in different props, to attract people's attention, and let the goods value at the same time improve their value. Slowly along with the development of the time, every industry in the display design, but in the garment industry, the display design is particularly important to the beauty of a clothing store is dependent on the display design. In the process of clothing sales, many consumers will be neat commodity display, the color of the goods, special props, attracted to the modelling of commodity and model posture. Therefore, store display is very important to attract the attention of consumers, now most stores have the specialist is responsible for the stores display, not regular update and adjust the goods location, let customers feel a new product every day, through the new things, to attract consumers, stimulate their purchasing desire, to realize the value of products.

Clothing store design and display design purpose and meaning. Clothing store design mainly in order to reflect the brand culture, promote concept of product, let consumer in the store of goods is full of curiosity, and through a unique store decoration, make consumers can clearly distinguish brand stores. Now, with independent intellectual property rights of the brand has a specific LOGO as the LOGO, allowing consumers to quickly identify the brand information, so more and more garment enterprises pay attention to promote their own clothing brand, clothing brand awareness is a kind of intangible brand value has increased, so the design of the clothing store is particularly important. Display is designed primarily to make fashion culture through product display, let consumer can intuitive understanding of the brand's main commodity in the quarter, to reflect the brand culture further. Only in the store display design combined with a store design can better show the brand culture.

Display design development present situation in our country. European clothing store optional put on the clothes before, a whim hang clothes up a shopkeeper, which attracted many customers, shop sales profits also rose, so a growing number of imitators, gradually formed a special display design. In Europe, the display design industry has high demands to the designer, not only requires degree, also request to have the keen market insight, to understand consumer preferences, thus giving consumers have to buy goods on display. But in recent years in our country began to develop display design, the position is very scarce, so the display design also has the very big development space in the future, in order to adapt to market demand for the industry requirements will be higher.

The influence of display design of clothing stores. In stores, most intuitive to show the product is displayed for the customer. Display through the visual art design technique, let the consumer feel commodity information directly, visual merchandising quality directly affects the consumer judgment of commodity information, will affect the consumption performance, so more and more garment enterprises take special idea on display design, through the display technique to attract consumers' attention, so as to improve store performance.

\section{The influence of display design of apparel sales}

Display design influence on consumers' consumption psychology. Display design is a unique visual art design, in the visual arts through clothing collocation, modelling, props, such as combination, not regularly adjust the display position, make the customer feel at any time there are new products, at the same time to create the perfect brand image and brand image is deeply rooted in the hearts of the people is a kind of potential advertising model, so it is easy to cultivate a large number of fixed customers, also strengthened the trust of consumers to the brand, so as to improve the added value of products, make the enterprise gain more profit. Good display is designed to appeal to consumers directly, let goods to realize maximum benefit.

Display design and brand culture. Many clothing brands have their own brand culture, most companies will reflect brand concept through product design, in the store, many shops will be combined with the main commodity in the quarter to show brand culture, through the combination of colors and clothing style display, let consumer simple contact brand culture. Brand in growing 
Numbers are beginning to pay attention to the brand culture propaganda, according to a certain consumer groups, let them know the brand culture, virtually would raise public awareness of the product, thus is advantageous to the enterprise in the market to occupy a certain market share.

Display design and clothing of the store sales. The shop clothing stores display design directly affects the sales. Most clothing store is based on sales performance, it is concluded that the stand or fall of stores display. A thousands of square meters of shops, after a large display, after the adjustment will be based on the second day sales analysis the success of this display adjustment. So store sales performance is the basis of stores display adjustment. Many stores will have the problem areas, these problem areas through data, analysis the bad sales product type, thus restructuring and the adjustment of the location of display the products. In today's rapid economic growth, many shops are in prime locations, so the real to do "before", still need through a variety of display technique, to attract consumers, that cause the consumer's purchase desire. Only through this kind of technique can improve corporate profits.

\section{The influence of clothing store design of clothing sales}

Store Windows, the main design factors including dynamic line design, color design, lighting design, these a few respects music design. Windows theme is different according to different season, every season has the corresponding window paint with image, store will be in accordance with the main commodity in the quarter through the model in the shop window display, at the same time use the display technique, based on modelling, props, posters, etc. To form a perfect window design. Window design directly affects the inside, so many shops will pay attention on the window, through the window to attract customers, which affect sales.

Process design is design for customer walking routes in stores, general stores according to the checkout counter and design the main import and export channels. By goods of different display position, has formed the second channel, second channel mainly for the convenience of our customers choose goods, not as a secure channel this role, so the general store will be in the main channel width than time, the width of the concrete will be according to the actual size of the shop.

Color design is an eternal research topic, the color design of the stores are all through the commodity color, most of the research team will pass out the next year the popular trend of the market research analysis, popular colour, then carries on the product design. Display for the customer, went to the store to see the main color, you can analyze the popular color this year. So it's very important to store display commodity color combination.

Lighting design directly affects the clothing sales of the shop. Assuming a shop no lights, everywhere is dark, is not a consumer is willing to consumption in the dark, so most of the stores are willing to spend money to buy good tube lights and shoot the light. Different lights in the stores will give people different visual effect, general store can according to the display of goods to choose the color of lamplight, elevated with island will use the focus of the canister light to shoot the light to show the administrative levels. Generally darker goods will improve product brightness by lighting, sometimes to the main focus of a model, also can use light to attract consumer attention.

Clothing brand positioning determines the type of music stores, such as pure mainly young customers, music will choose more dynamic, that coincide with the goods of the stores at the same time. The general brand clothing in different season have different music, allow consumers to distinguish clearly.

\section{Conclusion}

Through clothing stores display design and analysis of the effect of the clothing sales. In fact, is a factor to affect sales of clothing store design, it is complementary relationship and display design, both regarded. At the same time, according to the different situation, also on consumer psychology, brand culture has carried on the simple analysis. Brand by its brand culture, the design style of goods to determine consumer groups, according to the product into a design to display and store design. Successful brands mainly through the design of a certain brand image to reflect the brand culture, in stores often according to the brand image display technique is used to change the brand culture. Only the brand is deeply rooted in the hearts of the people, for the consumer potential 
consumer consciousness, improve the sales profit, to occupy a certain share in the market, thus play a leading role brand. There are more and more clothing brand, if you want to, must want to have their own management idea, to consumers as the center, time for customer service, to have the opportunity to lead the market.

\section{Reference}

[1] Yiqun Zhao. Clothing stores display design and marketing strategy [J]. Journal of China commerce and trade, 2010 (20).

[2] Lina Hu. Clothing display effect on clothing sales [J]. Science and technology, 2014 (01).

[3] Hengliang Tang. Introduction to brand clothing store display space design and the impact on sales [J]. Journal of beauty with the time (on), 2011 (11). 